\title{
KERAGAMAN SIMPANAN KARBON DALAM TIPE TANAH NITISOLS DAN FERRALSOLS DI KAWASAN HUTAN TANAMAN Pinus merkusii Jungh et. de Vriest DAN Shorea leprosula Miq. DI KABUPATEN BOGOR, PROVINSI JAWA BARAT (Variability of Soil Carbon Stock in Nitisols and Ferrasols Soil Types Under Pinus merkusii Jungh et. de Vriest and Shorea leprosula Miq. Plantation Areas in Bogor Regency, West Java Province)
}

\author{
Oleh/By: \\ Harris Herman Siringoringo \\ Pusat Litbang Hutan dan Konservasi Alam \\ Jl. Gunung Batu No. 5 Po Box 165; Telp. 0251-633234, 7520067; Fax 0251-638111 Bogor
}

*) Diterima : 13 Agustus 2007; Disetujui : 21 November 2007

\begin{abstract}
The main objective of this research is to examine spatial variability recognized by the quantity of cumulative carbon stock for two different soil types, i.e. Nitisols and Ferralsols under the newly establishment of Pinus merkusii Jungh. et de Vriest. and Shorea leprosula Miq., and including their baseline vegetations, respectively. Study sites were located in Cianten and Ngasuh Ranger Districts, under the management of Bogor Forest District, Unit III, State Forestry Coorporation of Indonesia, West Java and Banten. The climate conditions at respective locations were type A with annual rainfall of 4,561 $\mathrm{mm}$ for Cianten and type $B$ with annual rainfall 3,148 $\mathrm{mm}$ for Ngasuh. The results showed that bulk densities of the Nitisols were differently lower than those of the Ferralsols until $70 \mathrm{~cm}$ soil depth, and overall averages of bulk densities at $0-100 \mathrm{~cm}$ depth ranged between 0.38 to $0.70 \mathrm{~g} / \mathrm{cc}$ for Nitisols and 0.53 to $0.86 \mathrm{~g} / \mathrm{cc}$ for Ferralsol. Conversely, the carbon contents at the Nitisols were differently higher than those at the Ferralsols until $100 \mathrm{~cm}$ soil depth, and overall averages of the carbon content ranged at 0.58 to $11.84 \%$ for Nitisols and 1.18 to $6.07 \%$ for Ferralsol. Meanwhile, clay content at Nitisols was lower than that of Ferralsols at 0-100 cm depth, ranging at 78.6-87,6 \% and 39.30-53.30 \%, respectively. Cumulative soil carbon stocks of Nitisols at 0-50 $\mathrm{cm}$ depth were higher and significantly differed than that of Ferralsols, that was 127.13 ton/ha for Nitisols and 98.66 ton/ha for Ferralsols, respectively. Whereas, the CVs of soil carbon stock for Nitisols was much larger than that for Ferralsols, ranging between 20.29-43.91 \% and 8.56-10.55 \%, respectively. The required number of samples to estimate the carbon stock in the upper $30 \mathrm{~cm}$ of soil to get less than $5 \%$ error was higher in soils from steeper topography (i.e. Nitisols) and was lower in weathered soils (i.e. Ferralsols), those were 206 samples for Nitisols and 14 samples for Ferralsols. It is concluded that the different spatial variability in each soil type tends to be consistent with the degree of soil weathering. Beside that, the influence of steeper topography may have been another important factor causing higher heteregenity in Nitisols.
\end{abstract}

Key words: Soil type, plantation, cumulative soil carbon stock, spatial variability, required sample number

\begin{abstract}
ABSTRAK
Penelitian ini bertujuan untuk mendapatkan informasi tentang keragaman kondisi lahan yang dicirikan oleh besarnya simpanan karbon pada tanah Nitisols dan Ferralsols di kawasan hutan tanaman Pinus merkusii Jungh. et de Vriest dan Shorea leprosula Miq. yang baru ditanam, termasuk vegetasi awalnya, secara berurutan. Penelitian dilaksanakan di RPH Ngasuh dan RPH Cianten, keduanya merupakan lingkup wilayah kerja KPH Bogor, Unit III Perum Perhutani, Provinsi Jawa Barat dan Banten. Kondisi iklim di Ngasuh termasuk tipe B, sedangkan di Cianten tipe iklim A dengan rata-rata curah hujan tahunan berturut-turut sebesar $3.148 \mathrm{~mm}$ dan $4.561 \mathrm{~mm}$. Hasil penelitian menunjukkan bahwa kerapatan tanah Nitisols lebih rendah daripada tanah Ferralsols dan berbeda nyata hingga kedalaman tanah $70 \mathrm{~cm}$, dengan rata-rata total untuk kedalaman 0-100 cm berkisar antara 0,38-0,70 g/cc untuk Nitisols dan 0,53-0,86 g/cc untuk Ferralsols. Sebaliknya, kandungan karbon pada tanah Nitisols lebih tinggi daripada tipe Ferralsols dan berbeda nyata hingga pada kedalaman $50 \mathrm{~cm}$, dengan rata-rata total untuk kedalaman 0-100 cm berkisar antara 0,58-11,84 \% untuk Nitisols dan 1,18-6,07 \% untuk Ferralsols. Sementara, kadar liat tanah Nitisols lebih rendah dibanding dengan tanah Ferralsols, dengan rata-rata total untuk kedalaman 0-100 cm berkisar antara 39,3053,30 \% untuk Nitisols dan 78,60-87,60 \% untuk Ferralsols. Simpanan karbon tanah kumulatif pada tanah
\end{abstract}


Nitisols lebih besar daripada tanah Ferralsols dan berbeda nyata hingga kedalaman $50 \mathrm{~cm}$, yaitu sebesar 127,13 ton/ha untuk Nitisols dan 98,66 ton/ha untuk Ferralsols. Sedangkan koefisien keragaman simpanan karbon kumulatif pada tanah Nitisols lebih tinggi daripada tanah Ferralsols, berkisar antara 20,29-43,91 \% dan 8,56-10,55 \%, secara berurutan. Jumlah contoh tanah yang dibutuhkan untuk memperkirakan simpanan karbon dengan menghasilkan 5 \% kesalahan pada tingkat kepercayaan $95 \%$ pada kedalaman 0-30 cm adalah sebanyak 14 contoh untuk tanah Ferralsols dan setidaknya 206 contoh untuk tanah Nitisols. Dapat disimpulkan bahwa keragaman kondisi lahan yang berbeda pada masing-masing tipe tanah cenderung konsisten dengan tingkat pelapukan tanah. Di samping itu, pengaruh topografi yang curam mungkin menjadi salah satu faktor yang menyebabkan lebih tingginya heterogenitas pada tanah Nitisols.

Kata kunci : Tipe tanah, tegakan hutan, simpanan karbon tanah kumulatif, keragaman kondisi lahan, jumlah contoh yang diperlukan

\section{PENDAHULUAN}

\section{A. Latar Belakang}

Di luar dari batuan-batuan karbonat, tanah merupakan penyimpan karbon (C) terbesar pada ekosistem daratan. Tanah mengandung karbon kurang lebih 1.500 miliar ton (Batjes, 1996), sekitar dua kali lebih besar dari jumlah karbon atmosfer dan tiga kali lebih besar dari jumlah karbon pada vegetasi daratan (Smith, 2004). Di dalam tanah pada umumnya, kecuali tanah alkalin (calcareous soils), sebagian besar karbon disimpan dalam bentuk karbon organik tanah (Batjes and Sombroek, 1997).

Karbon organik tanah berperan penting terhadap fungsi ekosistem, terutama karena pengaruhnya terhadap struktur tanah, kapasitas menahan air, kapasitas pertukaran kation, kemampuan tanah untuk membentuk senyawa kompleks dengan ion-ion logam dan menyimpan hara. Pengelolaan tanah yang tepat, yaitu untuk meningkatkan jumlah bahan organik tanah yang pada dasarnya adalah karbon organik tanah, dapat memperbaiki produktivitas dan kesinambungan sistem pengelolaan lahan pertanian dalam artian yang luas (termasuk kehutanan, perkebunan, agroforestry, dan lainnya), dan sebaliknya, pengelolaan yang tidak tepat terhadap bahan organik tanah dapat menyebabkan degradasi lahan dan pada akhirnya akan bermuara pada problema penurunan kualitas lingkungan secara lokal, regional, maupun global. Faktor lain yang menyebabkan perubahan karbon organik tanah adalah perubahan pemanfaatan lahan seperti penebangan hutan, pengolahan dan introduksi padang rumput (Haughton et al., 1999), walaupun kecenderungan arah dan besarnya perubahan kadar C-organik tanah bervariasi sesuai dengan persentase penutupan lahan dan cara pengelolaan lahan (Baskin and Binkey, 1998; Hu et al., 1997; Van Noorwijk et al., 1997). Misalnya, konversi hutan menjadi lahan pertanian atau padang rumput, maka karbon organik tanah akan mengalami perubahan yang bervariasi dari satu tempat ke tempat lainnya. Perbedaan simpanan karbon di antara tanah-tanah padang rumput dihubungkan dengan keragaman dalam tipe vegetasi (Rhoades, 1997), umur padang rumput (Garcia-Oliva et al., 1994), dan sifat-sifat fisik tanah, khususnya mineralogi tanah (Parfitt et al., 1997).

Terlebih pada saat ini, tanah dan karbon organik tanah mendapat perhatian yang besar karena peranan pentingnya dalam mengurangi efek peningkatan karbon atmosfer bumi. Batjes (1999) memperkirakan bahwa dengan alih fungsi lahan dan pengelolaan yang tepat terhadap lahan pertanian, padang rumput maupun hutan, tanah berpotensi untuk mensekuestrasi/memindahkan karbon atmosfer kurang lebih sebesar $14 \pm 7 \mathrm{Pg}(1 \mathrm{Pg}=1$ miliar ton) secara global 25 tahun ke depan. Data tersebut menunjukkan bahwa laju sekuestrasi karbon tahunan berkisar antara 0,58-0,80 Pg setara dengan 9-12 
$\% \mathrm{CO}_{2}$-karbon yang dihasilkan dari aktivitas manusia (anthropogenic) setiap tahunnya. Bruce et al. (1999) memperkirakan sekuestrasi karbon atmosfer agak sedikit konservatif, yaitu sebesar 0,45-0,61 Pg per tahun. Sementara Lal (2004) merekomendasikan bahwa laju potensial sekuestrasi karbon sekitar 0,9 \pm 0,3 Pg per tahun. Perkiraan tersebut menunjukkan betapa penting peranan tanah dalam hal sekuestrasi karbon atmosfer.

Di sisi lain, tanah memiliki heterogenitas dan biasanya memperlihatkan suatu keragaman kondisi lahan (spatial variability) yang tinggi dalam hal berbagai parameter, termasuk kandungan karbon tanah, khususnya pada tanah hutan. Keragaman tersebut dapat disebabkan oleh banyak faktor termasuk tipe tanah, tipe penggunaan lahan, iklim, topografi, bahan induk tanah, gangguan pada lahan sebelumnya (disturbance history), serta proses-proses secara kimia-fisik-biologi yang terjadi pada tanah (Beckett and Webster, 1971; Dadal and Meyer, 1986). Selain itu, keragaman kondisi lahan dalam hal kandungan karbon organik tanah sangatlah tinggi bahkan dalam satu unit peta tanah (Melilo et al., 1984; Pastor and Post, 1986). Di samping itu, data dan informasi tentang spatial variability kandungan organik tanah pada skala yang lebih kecil sangat jarang tersedia khususnya pada daerah hutan tropika basah di Asia yang mewakili paling tidak sepertiga dari masa total karbon organik tanah secara global (Eswaran et al., 1993).

Oleh karena itu, penyelidikan perlu dilakukan secara terpadu terhadap keragaman pada suatu lahan yang mencakup keragaman tipe tanah, topografi, vegetasi, iklim, sistem pengelolaan, dan lainnya dalam kaitannya dengan simpanan karbon tanah pada suatu wilayah. Dengan demikian, data dan informasi dasar tersebut akan sangat berguna untuk dipergunakan sebagai acuan dalam pengembangan metodologi untuk memperkirakan secara lebih akurat jumlah, distribusi, dan fluktuasi karbon tanah pada suatu wilayah.

\section{B.Tujuan}

Penelitian ini bertujuan untuk mendapatkan data dan informasi tentang keragaman tempat/kondisi lahan (spatial variability) berdasarkan besarnya kandungan simpanan karbon tanah pada dua tipe tanah yang berbeda, yaitu Nitisols dan Ferralsols di kawasan hutan tanaman yang berbeda, yaitu Pinus merkusii Jungh. et deVriest dan Shorea leprosula Miq. termasuk pada masing-masing vegetasi awalnya, dengan kondisi topografi, ketinggian tempat, dan curah hujan yang berbeda di antara kedua tipe tanah. Selain itu, penelitian ini juga bertujuan untuk mendapatkan informasi tentang jumlah contoh tanah yang diperlukan dalam memperkirakan besarnya simpanan karbon pada kedua tipe tanah dengan suatu tingkat akurasi yang dapat dipercaya.

Hasil penelitian ini diharapkan dapat menjadi bahan informasi tentang keragaman dalam simpanan karbon tanah pada tipe tanah Nitisols maupun Ferralsols di kawasan hutan tanaman daerah tropika basah dalam memberikan kontribusi pada sekuestrasi karbon tanah (soil carbon sequestration) dan mitigasi pemanasan global.

\section{METODOLOGI}

\section{A. Deskripsi Umum Lokasi Penelitian}

Penelitian dilaksanakan di areal hutan tanaman Shorea leprosula Miq. di Resort Pemangkuan Hutan (RPH) Ngasuh $\left(6^{0} 33^{\prime}-6^{0} 34^{\prime}\right.$ S, $106^{0} 25^{\prime}-106^{0} 26^{\prime}$ E), Bagian Kesatuan Pemangkuan Hutan (BKPH) Jasinga dan areal hutan tanaman Pinus merkusii Jungh. et de Vriest di RPH Cianten $\left(6^{0} 44^{\prime}-6^{0} 45^{\prime} \mathrm{S}, 106^{0} 36^{\prime}-106^{0} 37^{\prime} \mathrm{E}\right)$, BKPH Leuwiliang. Kedua lokasi merupakan kawasan hutan sekunder muda, dan berada dalam wilayah kerja Kesatuan Pemangkuan Hutan (KPH) Bogor, Perum Perhutani Unit III Jawa Barat dan Banten.

Karakteristik kedua lokasi penelitian mempunyai karakteristik tipe tanah, iklim, ketinggian tempat, topografi, 
kemiringan lereng yang relatif berbeda. Tipe tanah di Ngasuh adalah Haplic Ferralsols atau Typic Hapludox dan di Cianten adalah Dystrict Nitisols atau Typic Hapludult (Siringoringo et al., 2003; Siregar et al., 2003), berdasarkan pada Word Reference Base for Soil Resources (FAO/ISRIC/ISSS, 1998) atau Soil Survey Staff (1999). Haplic Ferralsols terbentuk dari batuan endapan berumur Miocen yang bersifat masam (acidic Miocene sedimentary rocks), sedangkan Dystrict Nitisols terbentuk dari bahan induk batuan andesit yang bersifat masam. Topografi lokasi penelitian di RPH Ngasuh termasuk pada kategori bukit bergelombang (rolling hills), kemiringan lereng $\pm 0-20^{\circ}$; ketinggian tempat pada $\pm 250 \mathrm{~m}$ di atas permukaan laut (dpl), dan kondisi iklim termasuk tipe B dengan rata-rata curah hujan tahunan sebesar $3.148 \mathrm{~mm}$. Sedangkan topografi lokasi penelitian di $\mathrm{RPH}$ Cianten termasuk kategori datar hingga bergunung-gunung yang terpisah satu dengan lainnya dengan lereng yang relatif curam (steeply-dissected mountains), kemiringan lereng $\pm 5-45^{0}$; ketinggian tempat berada pada $\pm 900 \mathrm{~m}$ dpl; dan kondisi iklim termasuk tipe A dengan rata-rata curah hujan tahunan sebesar $4.561 \mathrm{~mm}$. Data curah hujan tersebut merupakan data primer rata-rata curah hujan tahunan selama lima tahun sejak tahun 1995 hingga 1999 yang tercatat di Stasiun Klimatologi Cikopomayan, Nanggung, Kecamatan Leuwiliang, Bogor.

\section{B. Metode}

\section{Pembuatan Plot}

Tabel 1 menjelaskan secara ringkas kondisi tapak setiap plot penarikan contoh (sampling plots) dan cara pengambilan contoh tanah. Pada setiap lokasi/tipe tanah terdiri dari dua plot penarikan contoh (paired sampling plot), yaitu plot hutan tanaman baru dan plot vegetasi awal/ baseline/control plot/hutan sekunder muda. Plot berpasangan pada setiap tipe tanah ditentukan untuk membandingkan simpanan karbon tanah, termasuk kandungan karbon tanah, kerapatan tanah, dan kadar liat tanah antara plot hutan tanaman baru ditanam (O) dan plot vegetasi awal (control plot/CP) yang ada pada satu bentangan lahan yang berdekatan. Pengambilan contoh tanah di Ngasuh (NS) dengan tipe Ferralsols dilakukan pada plot Shorea leprosula Miq. yang baru ditanam di Ngasuh (NS-O) dan pada plot vegetasi awalnya (NS-CP) yang didominasi oleh jenis Maesopsis eminii Engl. (kayu afrika). Sementara pengambilan contoh tanah di Cianten (CT) dengan tipe Nitisols dilakukan pada plot Pinus merkusii Jungh et de Vriest yang baru ditanam (CT-O) dan pada plot vegetasi awalnya (CT-CP) yang didominasi oleh jenis Maesopsis eminii Engl. dan Schima wallichii (DC) Korth. (puspa).

Plot pengambilan contoh tanah pada hutan tanaman yang baru ditanam pada setiap lokasi/tipe tanah (NS-0 dan CT-0) terdiri dari empat subplot (petak) yang berukuran $30 \mathrm{~m} \mathrm{x} 45 \mathrm{~m}$, dan di dalam setiap subplot ditentukan sebanyak 10 titik pengambilan contoh tanah. Sementara plot pengambilan contoh tanah di hutan sekunder muda pada kedua tipe tanah (NS-CP dan CT-CP) masing-masing terdiri dari 10 subplot yang berukuran $10 \mathrm{~m}$ x 10 m. Pada setiap subplot ditentukan sebanyak empat titik pengambilan contoh tanah (kecuali pada satu subplot pada CT-CP terdiri dari tiga titik) yang terletak pada keempat sisi tengah bagian luar petak bujur sangkar. Letak setiap subplot di-tentukan secara acak. Penyiapan lahan dengan cara penebangan vegetasi (slash land preparation) yang berupa pohon dan belukar pada plot hutan tanaman baru pada kedua lokasi penelitian dilaksanakan pada bulan Juni-Oktober tahun 2001, dan penanaman dilaksanakan pada bulan November-Desember 2001. Sedangkan pengambilan contoh tanah di kedua lokasi penelitian dilakukan sekitar 0-1 bulan setelah penanaman. 
Tabel (Table) 1. Deskripsi plot dan pola pengambilan contoh tanah (Plot description and soil sampling plot design)

\begin{tabular}{|c|c|c|c|c|c|c|c|c|}
\hline $\begin{array}{l}\text { Tipe tanah } \\
\text { (Soil type) }\end{array}$ & Plot & $\begin{array}{l}\text { Luas } \\
\text { areal } \\
\text { (Stand } \\
\text { area) } \\
\text { (ha) }\end{array}$ & $\begin{array}{l}\text { Ukuran } \\
\text { subplot } \\
\text { (Subplot } \\
\text { size) } \\
\text { (m) }\end{array}$ & $\begin{array}{c}\text { Jumlah } \\
\text { subplot } \\
\text { (Number } \\
\text { of } \\
\text { subplots) }\end{array}$ & $\begin{array}{l}\text { Jumlah total titik } \\
\text { pengambilan } \\
\text { contoh tanah } \\
\text { (Total number of } \\
\text { sampling points) }\end{array}$ & $\begin{array}{c}\text { Vegetasi } \\
\text { (Vegetation) }\end{array}$ & $\begin{array}{c}\text { Pohon } \\
\text { dominan } \\
\text { (Dominant } \\
\text { tree } \\
\text { species) }\end{array}$ & $\begin{array}{c}\text { Kerapatan } \\
\text { pohon (Tree } \\
\text { density), } \\
\text { pohon/ha } \\
\text { (Tree/ha) }\end{array}$ \\
\hline \multirow[t]{2}{*}{$\begin{array}{l}\text { Nitisols } \\
\text { Cianten) }\end{array}$} & СТ-СР & 10 & $10 \times 10$ & 10 & $39(4)^{1)}$ & $\begin{array}{c}\text { Hutan } \\
\text { sekunder muda }\end{array}$ & $\begin{array}{l}\text { Schima } \\
\text { walichii, } \\
\text { Maesopsis } \\
\text { eminii }\end{array}$ & - \\
\hline & CT-O & 5 & $30 \times 45$ & 4 & $40(5)$ & $\begin{array}{c}\text { Hutan tanaman } \\
\text { baru (umur } 0 \\
\text { tahun) }\end{array}$ & $\begin{array}{c}\text { Pinus } \\
\text { merkusii }\end{array}$ & 1.667 \\
\hline $\begin{array}{l}\text { Ferralsols } \\
\text { (Ngasuh) }\end{array}$ & NS-CP & 10 & $10 \times 10$ & 10 & $40(5)$ & $\begin{array}{c}\text { Hutan } \\
\text { sekunder muda }\end{array}$ & $\begin{array}{c}\text { Maesopsis } \\
\text { eminii }\end{array}$ & - \\
\hline
\end{tabular}

Keterangan (Remarks) : ${ }^{1)}$ Jumlah titik pengambilan contoh tanah pada kedalaman 0-30 cm (0-100 cm). Yang kemudian termasuk di dalam yang sebelumnya. Contoh tanah diambil dari lapisan tanah pada interval kedalaman $0-5 \mathrm{~cm}, 5-10 \mathrm{~cm}$, 10-20 cm, 20-30 cm, 30-50 cm, 50-70 cm, dan 70-100 cm (Number of soil sampling points for 0-30 cm (0$100 \mathrm{~cm}$ ). The latter is included in the former. Soil samples were collected from $0-5 \mathrm{~cm}, 5-10 \mathrm{~cm}, 10-20 \mathrm{~cm}$, 20-30 cm, 30-50 cm, 50-70 cm, and 70-100 cm soil depth).

\section{Pengambilan Contoh Tanah di Lapangan}

Pada plot hutan tanaman baru (NS-O) dan plot vegetasi awal (NS-CP) di Ngasuh dan plot hutan hutan tanaman baru di Cianten (CT-O), contoh tanah diambil dari 40 titik pengambilan contoh (soil sampling points) hingga pada kedalaman $30 \mathrm{~cm}$, dengan interval kedalaman 0-5 cm, 5-10 cm, $10-20 \mathrm{~cm}$, dan 20-30 cm; dan lima titik dari 40 titik, contoh tanah diambil hingga pada kedalaman $100 \mathrm{~cm}$ dengan interval kedalaman 0-5 cm, 5-10 cm, $10-20 \mathrm{~cm}, 20-30 \mathrm{~cm}, 30-50 \mathrm{~cm}, 50-$ $70 \mathrm{~cm}$, dan 70-100 cm. Sedangkan pada plot vegetasi awal di Cianten (CT-CP), contoh tanah diambil dari 39 titik hingga pada kedalaman $30 \mathrm{~cm}$; dan empat titik dari 39 titik, contoh tanah diambil hingga pada kedalaman $100 \mathrm{~cm}$ masing-masing dengan interval kedalaman yang sama dengan yang tersebut di atas. Contoh tanah diambil secara berurutan mulai dari lapisan teratas hingga lapisan terbawah dengan menggunakan stainless steel cylinder ring yang berukuran $20 \mathrm{~cm}^{2}$ x $5 \mathrm{~cm}$ (100 cc). Ring contoh tanah yang diperlukan sebanyak empat buah pada setiap lapisan tanah, terkecuali sebanyak enam buah untuk lapisan tanah 70-100 cm.
Ring contoh ditempatkan pada setiap lapisan tanah secara konsisten untuk mendapatkan contoh yang representatif. Contoh tanah pada setiap lapisan yang sama dikompositkan dan dimasukkan ke dalam kantong plastik, dan dibawa ke laboratorium untuk dianalisis lebih lanjut. Prosedur pengambilan contoh tanah yang digunakan berdasarkan metode yang digambarkan oleh Hatori (2003).

\section{Metode Penyiapan Contoh Tanah dan Analisis Karbon Tanah di Laboratorium}

Contoh tanah dikering-udarakan kurang lebih selama 1-2 minggu hingga beratnya stabil dan potongan akar dibuang dari contoh tanah. Berat tanah kering udara (Wt) ditimbang seluruhnya. Contoh tanah tersebut selanjutnya dihaluskan dengan menggunakan willey mill, dan disaring dengan ayakan berukuran $2 \mathrm{~mm}$ untuk memisahkan tanah halus $(<2 \mathrm{~mm})$ dari bebatuan/gravel (> $2 \mathrm{~mm}$ ). Berat bebatuan (Wg) ditimbang. Kerapatan tanah (BD) dan faktor kadar air tanah halus kering udara (MFf) dihitung. Untuk pengukuran karbon tanah dan penentuan faktor kadar air tanah bubuk halus (MFp), sekitar $20 \mathrm{~g}$ contoh tanah halus kering 
udara dihaluskan kembali hingga menjadi bubuk halus dengan menggunakan vibration mill. Bobot kering tanah pada suhu $105^{\circ} \mathrm{C}$ ditentukan dengan menggunakan oven, dan karbon tanah diukur dengan menggunakan NC analyzer.

\section{Perhitungan}

\section{Kerapatan Tanah (BD Tanah)}

Kerapatan tanah menurut Ohta (2001) dihitung berdasarkan persamaan berikut :

$$
\begin{aligned}
& \begin{array}{l}
\text { Kerapatan } \\
\text { Tanah }(\mathrm{g} / \mathrm{cc})
\end{array} \quad=\frac{(\mathrm{Wt}-\mathrm{Wg}) \mathrm{x}(1-\mathrm{MFf})}{4 \times \mathrm{Vr}(\mathrm{cc})} \ldots . . . .(1) \\
& \mathrm{MFf}
\end{aligned}
$$

\section{Simpanan Karbon Tanah}

Simpanan karbon tanah kumulatif pada kedalaman 0-100 cm dihitung dengan menjumlahkan simpanan karbon tanah pada setiap kedalaman $(0-5 \mathrm{~cm}, 5-10 \mathrm{~cm}$, 10-20 cm, 20-30 cm, 30-50 cm, 50-70 cm, dan 70-100 cm).

$$
\begin{aligned}
& \text { Simpanan karbon } \\
& \underset{\text { pada setiap }}{\text { dalaman (ton/ha) }}=\frac{\mathrm{T}(\mathrm{cm}) \times \mathrm{BD}(\mathrm{g} / \mathrm{cc}) \times \mathrm{Cs}(\%)}{(1-\mathrm{MFp})} \\
& \text { kedalaman (ton/ha) }
\end{aligned}
$$

\section{Jumlah Contoh yang Dibutuhkan}

Jumlah contoh tanah yang dibutuhkan (n) untuk menghasilkan pendugaan yang mempunyai taraf kepercayaan $95 \%$ dan nilai kesalahan di bawah $5 \%$ dihitung dengan menggunakan persamaan berikut (Boone et al., 1999) :

$\mathrm{n}=\mathrm{t}^{2} \mathrm{C}^{2} / \mathrm{E}^{2}$

Di mana :

$\mathrm{n}=$ jumlah contoh tanah yang dikumpulkan (the number of samples to be collected)

$\mathrm{t}=\mathrm{t}$ statistik Student yang sesuai pada taraf kepercayaan dan jumlah contoh yang dikumpulkan (Student's $t$ statistic appropriate for the level of confidence and number of samples being collected)

$\mathrm{C}=$ koefisen keragaman (coeficient of variation) (\%)

$\mathrm{E}=$ kesalahan yang dapat diterima sebagai bagian dari nilai rata-rata (the acceptable error as a proportion of the mean)

\section{Analisis Statistik}

Analisis keragaman satu arah (ANOVA) dengan menggunakan JMP Start Statistics (Sall et al., 2005) digunakan untuk membandingkan perbedaan kandungan karbon, BD tanah, kadar liat, dan simpanan karbon tanah berdasarkan tipe dan plot. Uji beda jujur (Honest Significant Difference, HSD) Tukey-Kramer digunakan untuk membandingkan besarnya perbedaan nilai tengah variabel kandungan karbon, BD, kadar liat, dan simpanan karbon tanah pada setiap perlakuan (tipe tanah, pasangan plot/paired plot, dan kedalaman).

\section{HASIL DAN PEMBAHASAN}

\section{A. Kerapatan Tanah, Kandungan Karbon, dan Kadar Liat pada Ke- dua Tipe Tanah}

Tabel 2 merangkum nilai rata-rata (mean) dan simpangan baku (SD) kandungan karbon tanah, kerapatan tanah, serta kadar liat tanah mulai dari lapisan atas hingga kedalaman $100 \mathrm{~cm}$ dengan selang kedalaman $0-5 \mathrm{~cm}, 5-10 \mathrm{~cm}, 10-$ $20 \mathrm{~cm}, 20-30 \mathrm{~cm}, 30-50 \mathrm{~cm}, 50-70 \mathrm{~cm}$, dan 70-100 cm pada tipe tanah Ferralsols (NS-CP dan NS-O) di Ngasuh dan pada tipe tanah Nitisols (CT-CP dan CT-O) di Cianten. 
Tabel (Table) 2. Kerapatan tanah, kandungan karbon, dan kadar liat pada setiap lapisan pada tipe tanah Ferralsols di Ngasuh, Bogor dan Nitisols di Cianten, Bogor (Bulk density, carbon content, and clay content of Ferralsols Ngasuh and Nitisols Cianten, Bogor for each layer)

\begin{tabular}{|c|c|c|c|c|c|c|c|c|c|}
\hline \multirow{2}{*}{$\begin{array}{l}\text { Soil } \\
\text { (Site) }\end{array}$} & \multirow{2}{*}{$\begin{array}{c}\text { Plot } \\
\text { (Plots) }\end{array}$} & \multirow{2}{*}{$\begin{array}{l}\text { Kedalaman } \\
\text { (Depth) } \\
\text { cm }\end{array}$} & \multirow{2}{*}{$\mathrm{N}$} & \multicolumn{2}{|c|}{$\begin{array}{c}\text { Kerapatan tanah, } \\
\text { BD (Bulk density) } \\
\text { g/cc }\end{array}$} & \multicolumn{2}{|c|}{$\begin{array}{c}\text { Kandungan karbon, } \\
\text { C (Carbon content) } \\
\%\end{array}$} & \multicolumn{2}{|c|}{$\begin{array}{c}\text { Liat (Clay) } \\
\%\end{array}$} \\
\hline & & & & $\begin{array}{c}\text { Rata-rata } \\
\text { (Mean) }\end{array}$ & $\mathrm{SD}$ & $\begin{array}{c}\text { Rata-rata } \\
\text { (Mean) }\end{array}$ & SD & $\begin{array}{c}\text { Rata-rata } \\
\text { (Mean) }\end{array}$ & SD \\
\hline \multirow{14}{*}{ Ferralsols } & \multirow[t]{7}{*}{ NS-CP } & $0-5$ & 40 & 0,53 & 0,06 & 6,07 & 0,84 & 78,6 & 2,9 \\
\hline & & $5-10$ & 40 & 0,64 & 0,05 & 4,6 & 0,78 & 79,4 & 2,2 \\
\hline & & $10-20$ & 40 & 0,68 & 0,05 & 3,54 & 0,54 & 79,4 & 1,9 \\
\hline & & $20-30$ & 40 & 0,72 & 0,05 & 2,7 & 0,41 & 81,2 & 3,6 \\
\hline & & $30-50$ & 40 & 0,8 & 0,07 & 1,63 & 0,26 & 82,0 & 1,9 \\
\hline & & $50-70$ & 40 & 0,84 & 0,07 & 1,42 & 0,21 & 81,6 & 1,9 \\
\hline & & $70-100$ & 40 & 0,86 & 0,04 & 1,18 & 0,2 & 81,6 & 2,9 \\
\hline & \multirow[t]{7}{*}{ NS-O } & $0-5$ & 40 & 0,57 & 0,09 & 5,85 & 0,82 & 84,4 & 5,3 \\
\hline & & $5-10$ & 40 & 0,67 & 0.08 & 4,30 & 0,68 & 84,2 & 3,9 \\
\hline & & $10-20$ & 40 & 0,69 & 0,07 & 3,58 & 0,58 & 82,4 & 3,2 \\
\hline & & $20-30$ & 40 & 0,73 & 0,06 & 2,83 & 0,47 & 85,0 & 4,3 \\
\hline & & $30-50$ & 40 & 0,76 & 0,06 & 2,08 & 0,33 & 87,0 & 4,5 \\
\hline & & $50-70$ & 40 & 0,8 & 0,03 & 1,61 & 0,17 & 87,2 & 3,7 \\
\hline & & $70-100$ & 40 & 0,82 & 0,06 & 1,25 & 0,16 & 87,6 & 2,5 \\
\hline \multirow{14}{*}{ Nitisols } & \multirow[t]{7}{*}{ CT-CP } & $0-5$ & 39 & 0,38 & 0,13 & 11,84 & 6,04 & 53,3 & 13,1 \\
\hline & & $5-10$ & 39 & 0,44 & 0,15 & 9,70 & 5,30 & 47,3 & 15,3 \\
\hline & & $10-20$ & 39 & 0,48 & 0,16 & 6,53 & 4,35 & 42,3 & 21,1 \\
\hline & & $20-30$ & 39 & 0,52 & 0,15 & 4,30 & 3,28 & 44,0 & 20,4 \\
\hline & & $30-50$ & 4 & 0,55 & 0,13 & 2,07 & 1,75 & 44,5 & 17,4 \\
\hline & & $50-70$ & 4 & 0,59 & 0,18 & 1,59 & 2,08 & 35,5 & 11,0 \\
\hline & & $70-100$ & 4 & 0,7 & 0,09 & 0,58 & 0,52 & 39,3 & 13,0 \\
\hline & \multirow[t]{7}{*}{ CT-O } & $0-5$ & 40 & 0,38 & 0,07 & 11,44 & 3,24 & 45,2 & 22,5 \\
\hline & & $5-10$ & 40 & 0,44 & 0,08 & 9,40 & 2,92 & 48,4 & 20,9 \\
\hline & & $10-20$ & 40 & 0,47 & 0,08 & 7,02 & 2,33 & 45,2 & 20,9 \\
\hline & & $20-30$ & 40 & 0,50 & 0,10 & 5,07 & 1,83 & 39,0 & 23,9 \\
\hline & & $30-50$ & 40 & 0,55 & 0,09 & 3,67 & 1,84 & 40,0 & 25,8 \\
\hline & & $50-70$ & 40 & 0,60 & 0,05 & 2,08 & 0,41 & 43,6 & 24,1 \\
\hline & & $70-100$ & 40 & 0,69 & 0,20 & 1,39 & 0,51 & 46,2 & 22,4 \\
\hline
\end{tabular}

\section{Kerapatan Tanah}

Kerapatan tanah (BD), di bawah kondisi jumlah curah hujan tahunan (different precipitation regimes) dan bentuk topografi (tinggi tempat, lereng) yang berbeda, bervariasi di antara kedua tipe tanah. Kerapatan tanah pada tanah Ferralsols bervariasi secara nyata dan lebih padat (tinggi) dibanding dengan kerapatan tanah pada tanah Nitisols (ANOVA satu arah, $\mathrm{p}<0,05$ ) pada setiap lapisan tanah hingga pada kedalaman $100 \mathrm{~cm}$ (Lampiran 1 dan Lampiran 2). Rata-rata keseluruhan kerapatan tanah pada kedalaman 0-100 cm berkisar antara 0,53-0,86 g/cc untuk tanah Ferralsols dan 0,38-0,69 g/cc untuk tanah Nitisols (Tabel 2). Sedangkan kerapatan tanah pasangan plot (paired plot) NS-O dan NS-CP pada tipe tanah Ferralsols lebih besar bila dibandingkan dengan kerapatan tanah pasangan plot CT-O dan CT-CP pada tipe tanah Nitisols dan menunjukkan perbedaan yang nyata hingga pada kedalaman $70 \mathrm{~cm}$. Sementara kerapatan tanah setiap plot pada setiap pasangan, antara plot NS-O dan plot NSCP pada tanah Ferralsols maupun antara plot CT-O dan plot CT-CP pada tanah Nitisols, secara statistik tidak menunjukkan perbedaan hingga pada kedalaman 0$100 \mathrm{~cm}$ (Lampiran 2).

Kerapatan tanah pada tipe tanah Nitisols di Cianten yang relatif lebih rendah dibandingkan dengan tipe tanah Ferralsols 
di Ngasuh berkaitan erat dengan kandungan karbon tanah yang lebih tinggi pada tanah Nitisols. Sudah menjadi parameter yang umum, besar-kecilnya kerapatan tanah/berat jenis suatu massa tanah dapat ditentukan dari data kandungan karbon tanahnya. Semakin besar kandungan karbon di dalam tanah semakin kecil kerapatan tanahnya, ataupun sebaliknya. Faktor-faktor lain yang mungkin menyebabkan kerapatan tanah Nitisol pada daerah pegunungan di Cianten relatif rendah adalah tingginya porositas tanah dari colloviums, yaitu suatu endapan campuran antara bahan tanah dan pecahan-pecahan batu yang terletak dekat dasar jurang atau lereng yang curam. Endapan tersebut tertumpuk/terakumulasi akibat antara lain pergerakan tanah secara perlahan (soil creep), longsor (slide), dan pencucian setempat (local wash). Selain itu, pengendapan kembali (redeposition) bahan tanah pada lereng-lereng yang relatif curam yang mana merupakan salah satu karakteristik tempat di mana tanah Nitisols biasanya terbentuk (FAO, 2006) adalah faktor yang juga mungkin menyebabkan rendahnya kerapatan tanah Nitisols.

\section{Kandungan Karbon Tanah}

Kandungan karbon bervariasi di antara kedua tipe tanah (Lampiran 3). Kandungan karbon pada tanah Nitisols berbeda sangat nyata dan lebih tinggi dibandingkan dengan tanah Ferralsols hingga pada kedalaman $50 \mathrm{~cm}$ (ANOVA satu arah, $\mathrm{p}<0,0001$ ). Walaupun kadar liat tanahnya lebih rendah, kandungan karbon tanah pada Nitisols hampir dua kali lebih besar daripada Ferralsols hingga pada kedalaman $30 \mathrm{~cm}$. Rata-rata keseluruhan kandungan karbon tanah pada kedalaman 0-100 cm berkisar 0,58-11,84 \% untuk Nitisols dan 1,18-6,07 \% untuk tanah Ferralsols (Tabel 2). Sedangkan kandungan karbon pasangan plot NS-O dan plot NS-CP pada tanah Ferralsols lebih kecil bila dibandingkan dengan pasangan plot CT-O dan plot CT-CP pada tanah Nitisols dan menunjukkan perbedaan secara nyata hingga pada kedalaman $30 \mathrm{~cm}$. Sementara kandungan karbon setiap plot pada setiap pasangan, antara plot hutan tanaman $S$. leprosula yang baru ditanam (NS-O) dan plot baseline-nya yang berupa hutan sekunder muda (NS-CP) yang didominasi jenis $M$. eminii pada tanah Ferralsols maupun antara plot hutan tanaman $P$. merkusii yang baru ditanam (CT-O) dan plot baseline-nya (CT-CP) yang didominasi oleh jenis $M$. eminii dan $S$. walichii pada tanah Nitisols, secara statistik tidak menunjukkan perbedaan hingga pada kedalaman 0-100 cm (Lampiran 4). Hal ini mengindikasikan bahwa penyiapan lahan dan diikuti penanaman pada masing-masing tipe tanah tidak berpengaruh terhadap perubahan kandungan karbon tanah paling tidak satu bulan setelah pembangunan hutan tanaman pada kedua lokasi/ tipe tanah.

Hasil penelitian Post et al. (1982) dan Bird et al. (1996) menunjukkan bahwa kandungan karbon tanah relatif lebih tinggi pada suatu daerah dengan kondisi iklim yang lebih dingin dibandingkan dengan daerah dengan iklim yang lebih panas. Pada skala regional, pola distribusi kandungan karbon organik di dalam tanah dihubungkan dengan pola curah hujan dan temperatur. Kandungan karbon organik tanah pada umumnya akan meningkat dengan meningkatnya curah hujan dan berkurang dengan meningkatnya temperatur (Burke et al., 1989).

Level karbon yang lebih tinggi pada tanah Nitisols di Cianten kemungkinan besar dipengaruhi oleh kondisi iklim tipe A dengan rata-rata curah hujan tahunan $4.561 \mathrm{~mm}$ pada ketinggian tempat \pm 900 $\mathrm{m}$ dpl, yang mana suhu atmosfer maupun tanahnya akan lebih dingin. Pada kondisi demikian, penguraian bahan organik pada tanah Nitisols di Cianten akan lebih lambat bila dibandingkan dengan tanah Ferralsol di Ngasuh yang kondisi iklimnya tipe B dengan rata-rata curah hujan tahunan $3.148 \mathrm{~mm}$ pada ketinggian tempat $\pm 250 \mathrm{~m} \mathrm{dpl}$. 


\section{Kadar Liat Tanah}

Berdasarkan Tabel 2, kadar liat ratarata keseluruhan tipe tanah Ferralsols jauh lebih tinggi dibandingkan dengan kadar liat tipe tanah Nitisols pada setiap lapisan tanah hingga kedalaman $100 \mathrm{~cm}$, yakni 78,6-87,6 \% untuk tanah Ferralsols dan 35,5-53,3 \% untuk tanah Nitisols. Hasil analisis keragaman kandungan liat berdasarkan tipe tanah pada Lampiran 5 menunjukkan perbedaan yang nyata (ANOVA satu arah, $\mathrm{p}<0,0001$ ). Kadar liat yang lebih tinggi pada tanah Ferralsols memungkinkan terjadinya pembentukan senyawa kompleks organik-mineral (organo-mineral-complexes) yang lebih tahan terhadap proses mineralisasi dan penguraian (Sanchez, 1976). Sedangkan kadar liat pada pasangan plot NS-O dan NS-CP pada tipe tanah Ferralsols lebih tinggi dibandingkan dengan kadar liat pada pasangan plot CT-O dan CT-CP pada tipe tanah Nitisols dan secara statistik menunjukkan perbedaan secara nyata. Sementara perbandingan kadar liat setiap plot pada setiap pasangan, antara plot NS-O dan plot NS-CP pada tanah Ferralsols maupun antara plot CT-O dan plot CT-CP pada tanah Nitisols, tidak berbeda secara statistik (Lampiran 6). Pada tanah Nitisols tekstur tanah bersifat lebih ringan di mana proporsi fraksi liat dari massa tanah lebih rendah. Sedangkan pada tanah Ferralsols tekstur tanahnya lebih berat karena proporsi fraksi liat hampir satu setengah kali lebih besar daripada tanah Nitisols. Hal ini berpengaruh pada kerapatan tanah di mana ruang-ruang pori mikro lebih dominan pada tanah Ferralsols, dan sebaliknya ruang pori makro lebih dominan pada tanah Nitisols.

Pada daerah tropis Australia, hasil penelitian Dadal dan Meyer (1986) menunjukkan bahwa laju hilangnya karbon organik tanah menurun secara eksponensial searah dengan peningkatan kadar liat. Selanjutnya, laju hilang karbon organik tanah juga menurun bila pembentukan agregat/butiran (agregasi) tanah meningkat karena perolehan karbon organik tanah yang diperlukan oleh mikroorganisma, enzim-enzim yang bersifat degradatif, dan mikroorganisma pengurai bahan organik lainnya menjadi berkurang.

\section{Keragaman Simpanan Karbon Ta- nah dan Jumlah Contoh yang Di- butuhkan}

Untuk mengetahui perbedaan simpanan karbon tanah kumulatif di antara kedua tipe tanah, data simpanan karbon tanah pada pasangan plot hutan tanaman baru dan vegetasi awalnya pada masingmasing tipe tanah digabungkan. Tabel 3 merangkum nilai rata-rata (mean), simpangan baku (SD), koefisien keragaman (CV) simpanan karbon tanah kumulatif, serta jumlah contoh yang dibutuhkan untuk mendapatkan nilai rata-rata simpanan karbon tanah kumulatif pada setiap kedalaman tertentu dengan kesalahan $5 \%$ pada tingkat kepercayaan $95 \%$ pada kedua tipe tanah.

Simpanan karbon tanah bervariasi di antara kedua tipe tanah (Lampiran 7). Simpanan karbon tanah Nitisols bervariasi nyata dan lebih besar dibandingkan dengan tanah Ferralsols pada kedalaman 0$5 \mathrm{~cm}, 0-10 \mathrm{~cm}, 0-20 \mathrm{~cm}, 0-30 \mathrm{~cm}(\mathrm{p}<$ 0,0001, ANOVA satu arah), dan 0-50 cm ( $<<0,05$, ANOVA satu arah). Namun pada kedalaman tanah lebih besar dari 50 cm, simpanan karbon tanah secara statistik tidak memperlihatkan perbedaan (Lampiran 7). Simpanan karbon tanah pada kedalaman 0-100 cm sebesar 167,82 ton/ha untuk tanah Nitisols dan 153,89 ton/ha untuk tanah Ferralsols.

Koefisien keragaman simpanan karbon tanah kumulatif, yang menggambarkan keragaman data relatif terhadap nilai rata-rata, tidak menunjukkan korelasi yang konsisten antara CV dan kedalaman tanah pada masing-masing tipe tanah. Koefisien keragaman rata-rata keseluruhan pada tipe Ferralsols lebih rendah (8,56-10,55 \%) dibanding dengan tipe Nitisols $(20,29-43,91 \%)$ pada setiap kedalaman (Tabel 2). 
Pada tanah Nitisols, tekstur tanah bersifat lebih ringan di mana proporsi fraksi liat dari massa tanah lebih rendah. Sedangkan pada tanah Ferralsols tekstur tanahnya lebih berat karena proporsi fraksi liat hampir satu setengah kali lebih besar daripada Nitisols. Hal ini berpengaruh pada kerapatan tanah di mana ruangruang pori mikro lebih dominan pada tipe tanah Ferralsols, sebaliknya ruang pori makro lebih dominan pada tipe tanah Nitisols. Kerapatan tanah yang lebih tinggi pada tanah Ferralsols mengakibatkan porositas tanahnya lebih rendah (ruang pori makro sedikit). Pada tanah Ferralsols yang terlapuk secara sempurna (wellweathering), kandungan karbon mungkin lebih terdistribusi secara merata di antara lapisan-lapisan tanah sebagai akibat, yaitu kurangnya ruang pori yang lebih kasar (makro pori), dan distribusi yang merata pori yang lebih halus (mikro pori). Pada kondisi demikian, bahan organik tanah yang telah terdekomposisi dan termineralisasi sebagian besar akan terjerap (occluded) di dalam semua ruang pori mikro dan mungkin secara fisik terlindungi dari media (agent) yang menguraikannya. Dengan proses mekanisme yang demikian, simpanan karbon tanah pada tipe tanah Ferralsols kemungkinan besar akan menghasilkan nilai keragaman/heterogenitas yang lebih rendah.

Sebaliknya, pada tanah Nitisols yang kurang terlapuk (less-weathered) menunjukkan heterogenitas dalam distribusi bahan organik kemungkinan karena lebih banyak penggabungan bahan organik melalui percampuran tanah oleh pergerakan tanah (soil creep) pada lereng yang relatif curam. Ditambah pula, pengaruh topografi mikro pada lereng yang lebih curam secara menonjol yang ditemukan pada tapak-tapak/teras berbukit-bukit mungkin salah satu faktor penting lainnya dalam meningkatkan heterogenitas simpanan karbon pada tanah Nitisols. Lapisan atas tanah/topsoil yang kaya dalam bahan organik cenderung bergerak ke tempat yang lebih rendah dan datar, membentuk suatu pola yang tak seimbang dalam distribusi karbon organik. Oleh karena itu, perbedaan level koefisien keragaman (CV) masing-masing tipe tanah tersebut kelihatannya konsisten dengan tingkat pelapukan pada masing-masing tipe tanah. Faktor lainnya, pada skala lokal, keragaman kandungan organik tanah pada suatu tipe tanah

Tabel (Table) 3. Simpanan karbon tanah kumulatif pada kedalaman berbeda pada tipe tanah Ferralsols di Ngasuh, Bogor dan Nitisols di Cianten, Bogor dan jumlah contoh yang diperlukan pada tingkat kepercayaan 95 \% (Carbon stocks of Ferralsols Ngasuh and Nitisols Cianten, Bogor at different depths and the required sample number at $95 \%$ confidence)

\begin{tabular}{|c|c|c|c|c|c|c|c|}
\hline \multirow{3}{*}{$\begin{array}{l}\text { Tipe tanah } \\
\text { (Soil type) }\end{array}$} & \multirow{3}{*}{$\begin{array}{c}\text { Plot } \\
(\text { Plots })\end{array}$} & \multirow{3}{*}{$\begin{array}{l}\text { Kedalaman } \\
\text { (Depths) } \\
\text { (cm) }\end{array}$} & \multirow{3}{*}{$\mathrm{N}$} & \multicolumn{3}{|c|}{$\begin{array}{l}\text { Simpanan karbon tanah kumulatif } \\
\text { (Cumulative soil carbon stock) }\end{array}$} & \multirow{2}{*}{$\begin{array}{c}\text { Jumlah contoh yang } \\
\text { diperlukan (Required } \\
\text { sample number) }\end{array}$} \\
\hline & & & & Rata-rata (Mean) & SD & $\mathrm{CV}$ & \\
\hline & & & & \multicolumn{2}{|l|}{ (ton/ha) } & $\%$ & Kesalahan $5 \%$ (5 \% error) \\
\hline \multirow{7}{*}{ (Ngasuh) } & NS-CP & $0-5$ & 80 & 16,16 & 1,53 & 9,45 & 14 \\
\hline & + & $0-10$ & 80 & 30,56 & 2,74 & 8,96 & 12 \\
\hline & \multirow[t]{5}{*}{ NS-0 } & $0-20$ & 80 & 54,83 & 5,38 & 9,8 & 15 \\
\hline & & $0-30$ & 80 & 74,72 & 7,04 & 9,42 & 14 \\
\hline & & $0-50$ & 10 & 98,66 & 10,41 & 10,55 & 17 \\
\hline & & $0-70$ & 10 & 123,38 & 12,29 & 9,96 & 15 \\
\hline & & $0-100$ & 10 & 153,89 & 13,17 & 8,56 & 11 \\
\hline \multirow{7}{*}{$\begin{array}{l}\text { Nitosol } \\
\text { (Cianten) }\end{array}$} & $\mathrm{CN}-\mathrm{CP}$ & $0-5$ & 79 & 20,90 & 9,17 & 43,91 & 296 \\
\hline & + & $0-10$ & 79 & 40,77 & 17,39 & 42,65 & 279 \\
\hline & \multirow[t]{5}{*}{$\mathrm{CN}-0$} & $0-20$ & 79 & 69,77 & 28,40 & 40,7 & 254 \\
\hline & & $0-30$ & 79 & 90,71 & 33,28 & 36,68 & 206 \\
\hline & & $0-50$ & 9 & 127,13 & 25,80 & 20,29 & 63 \\
\hline & & $0-70$ & 9 & 147,45 & 34,07 & 23,11 & 82 \\
\hline & & $0-100$ & 9 & 167,82 & 45,20 & 26,93 & 111 \\
\hline
\end{tabular}


secara umum dihubungkan dengan keragaman topografi dan posisi tempat di mana komposisi jenis tumbuhan berada. Bahkan pada skala lahan yang sangat kecil, yaitu pada jarak antara tanaman yang satu dengan yang lainnya (at the plantinterspace microsite scale), kandungan organik tanah cenderung terkonsentrasi di bawah vegetasi daripada terkonsentrasi pada lahan terbuka yang terletak di antara kedua vegetasi (Hook et al., 1991; Vinton and Burke, 1995; Derner et al., 1997; Burke et al., 1999).

Jumlah contoh tanah yang dibutuhkan untuk menghasilkan kesalahan tidak lebih dari $5 \%$ dengan tingkat kepercayaan 95 $\%$ terhadap nilai rata-rata simpanan karbon tanah bervariasi secara luas di antara kedua tipe tanah (Tabel 3), yang mana tipe tanah Ferralsols memerlukan jumlah contoh tanah yang jauh lebih sedikit dibanding dengan jumlah contoh tanah yang diperlukan tipe tanah Nitisols. Jumlah contoh tanah yang diperlukan untuk menduga nilai rata-rata simpanan karbon tanah kumulatif pada masing-masing tipe tanah pada lapisan atas tanah $(0-30 \mathrm{~cm})$ dengan kesalahan tidak lebih dari $5 \%$ adalah sebanyak 14 contoh tanah untuk Ferralsols dan setidaknya 206 contoh untuk tanah Nitisols. Sementara jumlah contoh yang diperlukan untuk menduga simpanan karbon tanah tipe Nitisols pada kedalaman 0-100 cm adalah sebanyak 111 contoh tanah, sekitar setengah dari jumlah yang dibutuhkan pada kedalaman 0-30 cm. Sedangkan jumlah contoh tanah yang dibutuhkan pada tipe tanah Ferralsols pada kedalaman 0-100 cm hampir sama dengan jumlah yang dibutuhkan pada lapisan tanah yang lebih dangkal. Oleh karena itu jumlah contoh yang dibutuhkan untuk mendapatkan suatu tingkat kesalahan tertentu sangat bervariasi antara tipe tanah yang satu dengan yang lainnya. Penyeragaman besarnya jumlah contoh yang diperlukan tidak dapat dilakukan walaupun pada suatu tipe tanah dalam suatu wilayah yang relatif kecil.

\section{KESIMPULAN DAN SARAN}

\section{A. Kesimpulan}

1. Kerapatan tanah pada tanah Nitisols berbeda sangat nyata dan lebih rendah dibandingkan dengan tanah Ferralsols hingga pada kedalaman $70 \mathrm{~cm}$ dari lapisan permukaan atas tanah. Rata-rata keseluruhan kerapatan tanah pada kedalaman 0-100 cm berkisar antara $0,38-0,70 \mathrm{~g} / \mathrm{cc}$ untuk tipe Nitisols dan 0,53-0,86 g/cc untuk tipe tanah Ferralsols. Sementara, kadar liat pada tanah Nitisols lebih rendah daripada tanah Ferralsols. Rata-rata keseluruhan kadar liat tanah pada kedalaman 0-100 cm berkisar antara 39,30-53,30 \% untuk Nitisols dan 78,60-87,60 \% untuk Ferralsols. Sebaliknya, kadar karbon pada tanah Nitisols berbeda sangat nyata dan lebih tinggi dibandingkan dengan tanah Ferralsols hingga pada kedalaman tanah $50 \mathrm{~cm}$. Kadar karbon tanah pada Nitisols hampir dua kali lebih besar daripada tanah Ferralsols pada kedalaman 0-30 cm. Rata-rata keseluruhan kandungan karbon tanah pada kedalaman 0-100 cm berkisar antara 0,58$11,84 \%$ untuk tipe Nitisols dan 1,186,07 \% untuk tipe tanah Ferralsols.

2. Kandungan karbon yang lebih tinggi pada tipe tanah Nitisols kemungkinan besar lebih dipengaruhi oleh faktor curah hujan yang tinggi dan suhu udara yang lebih rendah pada ketinggian tempat yang lebih tinggi.

3. Kandungan karbon pada hutan tanaman Shorea leprosula Miq. yang baru ditanam dan baseline-nya yang berupa hutan sekunder muda yang didominasi jenis Maesopsis eminii Engl. pada tanah Ferralsols maupun antara hutan tanaman Pinus merkusii Jungh et de Vriest yang baru ditanam dan plot baseline-nya yang didominasi oleh jenis Maesopsis eminii Engl. dan Schima walichii (DC) Korth. pada tanah Nitisols, secara statistik tidak 
menunjukkan perbedaan hingga pada kedalaman 0-100 cm.

4. Simpanan karbon kumulatif tanah Nitisols berbeda nyata dan lebih besar dibandingkan dengan tanah Ferralsols hingga pada kedalaman $0-50 \mathrm{~cm}$, yaitu sebesar 127,13 ton/ha untuk Nitisols dan 98,66 ton/ha untuk Ferralsols, dan tidak berbeda secara statistik pada kedalaman tanah lebih besar dari $50 \mathrm{~cm}$.

5. Koefisien keragaman (CV) keseluruhan simpanan karbon tanah Nitisols berkisar antara 20,29-43,91 \% dan lebih tinggi daripada tipe tanah Ferralsols yang berkisar antara 8,56-10,55 \%. Perbedaan level CV antara tanah Nitisols dan Ferralsols cenderung konsisten dengan tingkat pelapukan tanah. Pengaruh topografi yang curam mungkin merupakan salah satu faktor utama lainnya yang menyebabkan heterogenitas (CV) yang lebih tinggi terhadap simpanan karbon pada tanah Nitisols di Cianten.

6. Jumlah contoh tanah yang dibutuhkan untuk menghasilkan kesalahan lebih kecil dari $5 \%$ dengan tingkat kepercayaan $95 \%$ terhadap nilai rata-rata simpanan karbon tanah bervariasi sangat nyata di antara kedua tipe tanah, yaitu sebanyak 14 contoh untuk tanah Ferralsols dan setidaknya 206 contoh untuk tanah Nitisols pada lapisan olah tanah $(0-30 \mathrm{~cm})$.

\section{B. Saran}

Penelitian tentang karbon tanah perlu dikembangkan lebih lanjut dengan mempertimbangkan aspek-aspek variasi tipe tanah, kandungan liat, jenis vegetasi, tipe iklim, bentuk topografi, sistem pengelolaan lahan yang diterapkan, serta aspek lainnya yang berpengaruh terhadap simpanan karbon tanah. Dengan demikian pada akhirnya akan didapat suatu database yang lebih komprehensif mengenai simpanan karbon tanah pada berbagai ekosistem hutan di Indonesia yang beragam.

\section{DAFTAR PUSTAKA}

Baskin, M. and D. Binkey. 1998. Changes in Soil Carbon Following Afforestation in Hawaii. Ecology 79 : 828-833.

Batjes, N.H. 1996. Total Carbon and Nitrogen in the Soils of the World. Eur. J. Soil Scie. 47 (2) : 151-163.

Batjes, N.H. 1999. Management Options for Reducing $\mathrm{CO}_{2}$ Concentrations in the Atmosphere by Increasing Carbon Sequestration in the Soil. Report 410200-031. Dutch National Research Programme on Global Air Pollution and Climate Change (also published as : Tecnical Paper 30, International Soil Reference and Information Centre, Wageningen, Bilthoven).

Batjes, N.H. and W.G. Sonbroek. 1997. Possibilities for Carbon Sequestration in Tropical and Sub-tropical Soils. Glob. Change Biol. 3 (2) : 161173.

Beckett, P.H.T and R. Webster. 1971. Soil Variability : A Review. Soil Fertilizers 34 : 1-15.

Bruce, J., S. Forsyth, and M. Bishop. 1999. Final Report for National Climate Change Sinks Issues Table on Soil Carbon Sinks Potential in Key Countries. Pld. Global Change Strategies International Inc. Ottawa, Canada.

Bird, M.I., A.R.Chivas, J. Head. 1996. A Latitudinal Gradient in Carbon Turnover Times in Forest Soils. Nature $381: 143-146$.

Boone, R.D., D.F. Grigal, P. Sollins, R.J. Ahrens, and D.E. Amstrong. 1999. Soil Sampling, Preparation, Archiving, and Quality Control. In Robertson, G.P., D.C. Coleman, C. S. Bledsoe, P. Sollins (Eds.). Standard Soil Methods for Long-term Ecological Research. Oxford Univ. Press, New York : 3-28.

Burke, I.C., C.M. Yonker, W.J. Parton, C.V. Cole, K. Flach, and D.S. Schimel. 1989. Texture, Climate and Cultivation Effects on Soil Organic 
Matter Content in U.S. Grassland Soils. Soil Science Scociety of America Journal 53 : 800-805.

Burke, I.C., W.K. Laurentroth, R. Riggle, P. Brannen, B. Madigan, and S. Beard. 1999. Spatial Variability of Soil Properties in the Shortgrass Steppe : The Relative Importance of Topography, Grazing, Microsite, and Plant Species in Controlling Spatial Patterns. Ecosystems 2 : 422-438.

Dadal R. C. and R. J. Meyer. 1986. Longterms Trends in Fertility of Soils Under Continous Cultivation and Cereal Cropping in Southern Queensland II. Total Organic Carbon and its Rate of Loss from the Soil Profile. Australia Journal Soil Resources 24 : 281-292.

Derner, J.D., D.D. Briske, and T.W. Boutton. 1997. Does Grazing Mediate Soil Carbon and Nitrogen Accumulation Beneath $\mathrm{C}_{4}$ Perennial Grasses Along an Environmental Gradient? Plant and Soil 191 : 147-156.

Eswaran H., E. Van Der Berg, and P.F. Reich. 1993. Organic Carbon in Soils of the World. Soil Sci. Soc. Am. J. 57: 192-195.

FAO. 2006. World Reference Base for Soil Resources 2006. A Framework for International Classification, Correlation and Communication. World Soil Resources Report 103. FAO, Rome.

FAO/ISRIC/ISSS. 1998. World Reference Base for Soil Resources. World Soil Resources Report No. 84. FAO, Rome.

Garcia-Oliva, F., I. Cesar, P. Morales, and J.M. Maass. 1994. Forest-toPasture Conversion Influences on Soil Organic Carbon Dynamics in a Tropical Decidous Forest. Oecologia 99 : 392-396.

Hatori, H. 2003. Soil Analysis Report. Carbon Fixing Forest Management Project. Japan International Cooperation Agency and Forestry Research and Development Agency. Ministry of Forestry, Indonesia.
Haughton, R. A., J.L. Hacker, and K.T. Lawrence. 1999. Carbon Budget : Contribution from Land-use Change. Science 285 : 574-578.

Hook, P.B., I.C. Burke, and W.K. Laurenroth. 1991. Heterogenity of Soil and Plant $\mathrm{N}$ and $\mathrm{C}$ Associated with Individual Plants and Openings in North American Shortgrass Steppe. Plant and Soil 138 : 247-256.

Hu, S., D.C. Coleman, C.R. Caroll, P.F. Hendrix, M.H. Beare. 1997. Labile Soil Carbon Pools in Subtropical Forest and Agricultural Ecosystems as Influences by Management Practices and Vegetation Types. Agriculture, Ecosystems and Environment 65 : 6978.

Lal, R. 2004. Soil Carbon Sequestration to Mitigate Climate Change. Geoderma $123: 1-22$.

Melilo, J.M., R.J. Naiman, J.D. Aber, and A.E. Linkins. 1984. Factor Controlling Mass Loss and Nitrogen Dynamics of Plant Litter Decaying in Northern Streams. Bul. Mar. Sci. 35 : 341-356.

Ohta, S. 2001. Outlined Procedure of Soil Survey and Soil Sampling (Draft). Carbon Fixing Forest Management Project. Japan International Cooperation Agency and Forestry Research and Development Agency. Ministry of Forestry, Indonesia : pp. 7 (Tidak dipublikasikan).

Parfitt, R., B. Theng, J. Whinton, and T. Shepherd. 1997. Effects of Clay Minerals and Land Use on Organic Matter Pools. Geoderma 75 : 1-12.

Pastor, J. and W.M. Post. 1986. Influence of Climate, Soil Moisture and Succession on Forest Carbon and Nitrogen Cycles. Biogeochemistry 2 : 327.

Post, W.M., W.R. Emmanuel, P.J. Zinke, and A.G. Stangenberger. 1982. Soil Carbon Pools and World Life Zones. Nature 298 : 156-159.

Rhoades, C.C. 1997. Soil Carbon Nitrogen Changes Following Conversion 
of Equadorian Lower Montane Forest to Pasture. University of Georgia.

Sall, J., L. Creighton, and A. Lehman. 2005. JMP Start Statistics. A Guide to Statistics and Data Analysis Using JMP and JMP in Sofware. Thomson Learning Academic Resource Center. Third Edition : pp. 560.

Sanchez, P.A. 1976. Properties and Management of Soils in the Tropics. Department of Soil Science, North Caroline State University, John Wiley and Sons Inc. New York-ChichesterBrisbane-Toronto-Singapore : 417421.

Soil Survey Staff. 1999. Keys to Soil Taxonomy. USDA Natural Resources Conservation Service, Washington DC. Siregar, C.A., H. H. Siringoringo, and H. Hatori. 2003. Analysis of Soil Carbon Accumulation of Shorea leprosula Plantation in Ngasuh, West Java. Buletin Penelitian Hutan 634 : 79-92.
Pusat Penelitian dan Pengembangan Hutan dan Konservasi Alam. Bogor.

Siringoringo, H.H., C. A. Siregar, and H. Hatori. 2003. Analysis of Soil Carbon Accumulation of Pinus merkusii Plantation in Maribaya, West Java. Buletin Penelitian Hutan 634 : 93104. Pusat Penelitian dan Pengembangan Hutan dan Konservasi Alam. Bogor.

Smith, P. 2004. Soils as Carbon Sinks-the Global Context. Soil Use Manage 20 : 212-218.

Van Noorwijk, M., P.L. Woomer, P. Cerri, M. Bernoux, and K. Nugroho. 1997. Soil Carbon in the Humid Tropical Forest Zone. Geoderma 79 : 187-225.

Vinton, M.M. and I.C. Burke. 1995. Interactions Between Individual Plant Species and Soil Nutrient Status in Shortgrass Steppe. Ecology 76 (4) : 1116-1133.

Lampiran (Appendix) 1. Analisis keragaman kerapatan tanah berdasarkan dua tipe tanah yang berbeda pada setiap kedalaman (Analysis of variance of bulk density by two different soil types for each depth)

\begin{tabular}{|c|c|c|c|c|c|c|}
\hline $\begin{array}{c}\text { Kedalaman } \\
\text { (Depth), } \\
\text { cm }\end{array}$ & $\begin{array}{l}\text { Sumber keragaman } \\
\text { (Source of variation) }\end{array}$ & $\begin{array}{l}\mathrm{Db} \\
(d f)\end{array}$ & $\begin{array}{l}\text { Jumlah } \\
\text { kuadrat } \\
\text { (Sum of } \\
\text { square) }\end{array}$ & $\begin{array}{c}\text { Rata-rata } \\
\text { kuadrat } \\
\text { (Mean of } \\
\text { square) }\end{array}$ & $\begin{array}{l}\text { F-rasio } \\
(\text { F-ratio })\end{array}$ & $\begin{array}{c}\text { Prob }> \\
\text { F }\end{array}$ \\
\hline \multirow{3}{*}{$0-5$} & Tipe tanah (Soil type) & 1 & 1,17 & 1,17 & 141,03 & $<, 0001$ \\
\hline & Galat (Error) & 157 & 1,30 & 0,008 & & \\
\hline & Total terkoreksi (Corrected total) & 158 & 2,48 & & & \\
\hline \multirow{3}{*}{$5-10$} & Tipe tanah (Soil type) & 1 & 1,77 & 1,77 & 182,64 & $<, 0001$ \\
\hline & Galat (Error) & 157 & 1,52 & 0,01 & & \\
\hline & Total terkoreksi (Corrected total) & 158 & 3,28 & & & \\
\hline \multirow{3}{*}{$10-20$} & Tipe tanah (Soil type) & 1 & 1,85 & 1,85 & 193,17 & $<, 0001$ \\
\hline & Galat (Error) & 157 & 1,50 & 0,01 & & \\
\hline & Total terkoreksi (Corrected total) & 158 & 3,36 & & & \\
\hline \multirow{3}{*}{$20-30$} & Tipe tanah (Soil type) & 1 & 1,84 & 1,84 & 193,89 & $<, 0001$ \\
\hline & Galat (Error) & 157 & 1,49 & 0,01 & & \\
\hline & Total terkoreksi (Corrected total) & 158 & 3,33 & & & \\
\hline \multirow{3}{*}{$30-50$} & Tipe tanah (Soil type) & 1 & 0,26 & 0,26 & 33,02 & $<, 0001$ \\
\hline & Galat (Error) & 17 & 0,13 & 0,008 & & \\
\hline & Total terkoreksi (Corrected total) & 18 & 0,39 & & & \\
\hline \multirow{3}{*}{$50-70$} & Tipe tanah (Soil type) & 1 & 0,24 & 0,24 & 26,36 & $<, 0001$ \\
\hline & Galat (Error) & 17 & 0,16 & 0,009 & & \\
\hline & Total terkoreksi (Corrected total) & 18 & 0,40 & & & \\
\hline \multirow{3}{*}{$70-100$} & Tipe tanah (Soil type) & 1 & 0,10 & 0,10 & 7,95 & 0,0118 \\
\hline & Galat (Error) & 17 & 0,21 & 0,01 & & \\
\hline & Total terkoreksi (Corrected total) & 18 & 0,31 & & & \\
\hline
\end{tabular}


Lampiran (Appendix) 2. Perbandingan nilai rata-rata kerapatan tanah berdasarkan plot pada dua tipe tanah yang berbeda pada setiap kedalaman (Comparisons of soil bulk-density mean value by plot of the two different soil types for each depth)

\begin{tabular}{lllllllll}
\hline \multirow{2}{*}{$\begin{array}{l}\text { Tipe tanah } \\
\text { (Soil type) }\end{array}$} & \multirow{2}{*}{ Plot } & \multicolumn{5}{c}{$\begin{array}{c}\text { Nilai rata-rata kerapatan tanah pada setiap kedalaman } \\
\text { (Mean values of soil bulk density for each depth) }\end{array}$} \\
\cline { 3 - 8 } & & $0-5 \mathrm{~cm}$ & $5-10 \mathrm{~cm}$ & $10-20 \mathrm{~cm}$ & $20-30 \mathrm{~cm}$ & $30-50 \mathrm{~cm}$ & $50-70 \mathrm{~cm}$ & $70-100 \mathrm{~cm}$ \\
\hline Ferralsols & NS-0 & $0,57^{\mathrm{a}}$ & $0,67^{\mathrm{a}}$ & $0,69^{\mathrm{a}}$ & $0,73^{\mathrm{a}}$ & $0,76^{\mathrm{a}}$ & $0,80^{\mathrm{a}}$ & $0,82^{\mathrm{a}}$ \\
& NS-CP & $0,53^{\mathrm{a}}$ & $0,64^{\mathrm{a}}$ & $0,68^{\mathrm{a}}$ & $0,72^{\mathrm{a}}$ & $0,80^{\mathrm{a}}$ & $0,84^{\mathrm{a}}$ & $0,86^{{ }^{\mathrm{a}}}$ \\
\hline Nitisols & CT-O & $0,38^{\mathrm{b}}$ & $0,44^{\mathrm{b}}$ & $0,47^{\mathrm{b}}$ & $0,50^{\mathrm{b}}$ & $0,55^{\mathrm{b}}$ & $0,60^{\mathrm{b}}$ & $0,69^{\mathrm{a}}$ \\
& CT-CP & $0,38^{\mathrm{b}}$ & $0,44^{\mathrm{b}}$ & $0,47^{\mathrm{b}}$ & $0,52^{\mathrm{b}}$ & $0,54^{\mathrm{b}}$ & $0,58^{\mathrm{b}}$ & $0,70^{\mathrm{a}}$ \\
\hline
\end{tabular}

Keterangan (Remarks) : Nilai rata-rata di dalam kolom yang sama diikuti huruf yang berbeda adalah berbeda nyata pada taraf $5 \%$ menurut uji HSD Tukey-Kramer (Mean values in the same column followed by the different letter are significantly different at $5 \%$ level according to Tukey-Kramer HSD test)

Lampiran (Appendix) 3. Analisis keragaman kandungan karbon berdasarkan tipe tanah pada setiap kedalaman (Analysis of variance of carbon content by soil type for each depth)

\begin{tabular}{|c|c|c|c|c|c|c|}
\hline $\begin{array}{c}\text { Kedalaman } \\
\text { (Depth), } \\
\text { cm }\end{array}$ & $\begin{array}{l}\text { Sumber keragaman } \\
\text { (Source of variation) }\end{array}$ & $\begin{array}{l}\mathrm{Db} \\
(d f)\end{array}$ & $\begin{array}{l}\text { Jumlah } \\
\text { kuadrat } \\
\text { (Sum of } \\
\text { square) }\end{array}$ & $\begin{array}{c}\text { Rata-rata } \\
\text { kuadrat } \\
\text { (Mean of } \\
\text { square) }\end{array}$ & $\begin{array}{l}\text { F-rasio } \\
(\text { F-ratio })\end{array}$ & $\begin{array}{l}\text { Prob }> \\
\quad F\end{array}$ \\
\hline \multirow{3}{*}{$0-5$} & Tipe tanah (Soil type) & 1 & 1283,23 & 1283,23 & 108,63 & $<, 0001$ \\
\hline & Galat (Error) & 157 & 1854,60 & 11,81 & & \\
\hline & Total terkoreksi (Corrected total) & 158 & 3137,83 & & & \\
\hline \multirow{3}{*}{$5-10$} & Tipe tanah (Soil type) & 1 & 1031,05 & 1031,05 & 112,09 & $<, 0001$ \\
\hline & Galat (Error) & 157 & 1444,12 & 9,20 & & \\
\hline & Total terkoreksi (Corrected total) & 158 & 2475,17 & & & \\
\hline \multirow{3}{*}{$10-20$} & Tipe tanah (Soil type) & 1 & 411,84 & 411,84 & 68,54 & $<, 0001$ \\
\hline & Galat (Error) & 157 & 943,33 & 6,01 & & \\
\hline & Total terkoreksi (Corrected total) & 158 & 1355,16 & & & \\
\hline \multirow{3}{*}{$20-30$} & Tipe tanah (Soil type) & 1 & 148,04 & 148,04 & 40,97 & $<, 0001$ \\
\hline & Galat (Error) & 157 & 567,33 & 3,61 & & \\
\hline & Total terkoreksi (Corrected total) & 158 & 715,37 & & & \\
\hline \multirow{3}{*}{$30-50$} & Tipe tanah (Soil type) & 1 & 8,25 & 8,25 & 5,57 & 0,0305 \\
\hline & Galat (Error) & 17 & 25,17 & 1,48 & & \\
\hline & Total terkoreksi (Corrected total) & 18 & 33,42 & & & \\
\hline \multirow{3}{*}{$50-70$} & Tipe tanah (Soil type) & 1 & 1,25 & 1,25 & 1,37 & 0,2587 \\
\hline & Galat (Error) & 17 & 15,52 & 0,91 & & \\
\hline & Total terkoreksi (Corrected total) & 18 & 16,76 & & & \\
\hline \multirow{3}{*}{$70-100$} & Tipe tanah (Soil type) & 1 & 0,08 & 0,08 & 0,46 & 0,5080 \\
\hline & Galat (Error) & 17 & 3,15 & 0,18 & & \\
\hline & Total terkoreksi (Corrected total) & 18 & 3,23 & & & \\
\hline
\end{tabular}

Lampiran (Appendix) 4. Perbandingan nilai rata-rata kandungan karbon tanah berdasarkan plot pada dua tipe tanah yang berbeda pada setiap kedalaman (Comparisons of mean values of soil carbon content by plot of the two different soil types for each depth)

\begin{tabular}{llllllll}
\hline \multirow{2}{*}{ Plot (Plot) $)$} & \multicolumn{5}{c}{$\begin{array}{c}\text { Rata-rata kandungan karbon pada setiap kedalaman } \\
\text { (Mean value of carbon content for each depth) }\end{array}$} \\
\cline { 2 - 7 } & \multicolumn{1}{c}{$5-5 \mathrm{~cm}$} & $5-10 \mathrm{~cm}$ & $10-20 \mathrm{~cm}$ & $20-30 \mathrm{~cm}$ & $30-50 \mathrm{~cm}$ & $50-70 \mathrm{~cm}$ & $70-100 \mathrm{~cm}$ \\
\hline CT-O & $11,44^{\mathrm{a}}$ & $9,40^{\mathrm{a}}$ & $7,02^{\mathrm{a}}$ & $5,07^{\mathrm{a}}$ & $3,67^{\mathrm{a}}$ & $2,08^{\mathrm{a}}$ & $1,39^{\mathrm{a}}$ \\
CT-CP & $11,84^{\mathrm{a}}$ & $9,70^{\mathrm{a}}$ & $6,53^{\mathrm{a}}$ & $4,30^{\mathrm{a}}$ & $2,55^{\mathrm{a}}$ & $1,96^{\mathrm{a}}$ & $0,70^{\mathrm{a}}$ \\
NS-O & $5,85^{\mathrm{b}}$ & $4,30^{\mathrm{b}}$ & $3,58^{\mathrm{b}}$ & $2,82^{\mathrm{b}}$ & $2,08^{\mathrm{a}}$ & $1,61^{\mathrm{a}}$ & $1,28^{\mathrm{a}}$ \\
NS-CP & $6,07^{\mathrm{b}}$ & $4,60^{\mathrm{b}}$ & $3,54^{\mathrm{b}}$ & $2,70^{\mathrm{b}}$ & $1,63^{\mathrm{a}}$ & $1,42^{\mathrm{a}}$ & $1,18^{\mathrm{a}}$ \\
\hline
\end{tabular}

Keterangan (Remarks) : Nilai rata-rata di dalam kolom yang sama diikuti huruf yang berbeda adalah berbeda nyata pada taraf 5 \% menurut uji HSD Tukey-Kramer (Mean values in the same column followed by the different letter are significantly different at $5 \%$ level according to Tukey-Kramer HSD test) 
Lampiran (Appendix) 5. Analisis keragaman kandungan liat berdasarkan tipe tanah (Analysis of variance of clay content by soil type)

\begin{tabular}{lllllc}
\hline \multicolumn{1}{c}{$\begin{array}{c}\text { Sumber keragaman } \\
\text { (Source of variation) }\end{array}$} & $\begin{array}{l}\text { Db } \\
(d f)\end{array}$ & $\begin{array}{l}\text { Jumlah kuadrat } \\
\text { (Sum of square) }\end{array}$ & $\begin{array}{l}\text { Rata-rata kuadrat } \\
\text { (Mean of square) }\end{array}$ & $\begin{array}{c}\text { F-rasio } \\
(\text { F-ratio) }\end{array}$ & $\begin{array}{c}\text { Prob }> \\
\text { F }\end{array}$ \\
\hline Tipe tanah (Soil type) & 1 & 10717,32 & 10717,30 & 735,72 & $<, 0001$ \\
Galat (Error) & 26 & 378,74 & 14,60 & & \\
Total terkoreksi (Corrected total) & 27 & 11096,06 & & \\
\hline
\end{tabular}

Lampiran (Appendix) 6. Perbandingan nilai rata-rata kadar liat tanah berdasarkan plot pada dua tipe tanah yang berbeda pada kedalaman 0-100 cm (Comparisons of mean values of soil clay content by plot of the two different soil types for 0-100 cm depth)

\begin{tabular}{cc}
\hline Plot (Plot) & Nilai rata-rata kandungan liat (Mean values of carbon content) \\
\hline NS-O & $85,40^{\mathrm{a}}$ \\
NS-CP & $80,54^{\mathrm{a}}$ \\
CT-O & $43,94^{\mathrm{b}}$ \\
CT-CP & $43,74^{\mathrm{b}}$ \\
\hline
\end{tabular}

Keterangan (Remarks) : Nilai rata-rata di dalam kolom yang sama diikuti huruf yang berbeda adalah berbeda nyata pada taraf 5 \% menurut uji HSD Tukey-Kramer (Mean values in the same column followed by the different letter are significantly different at $5 \%$ level according to Tukey-Kramer HSD test)

Lampiran (Appendix) 7. Analisis keragaman simpanan karbon kumulatif berdasarkan tipe tanah pada setiap kedalaman (Analysis of variance of kumulative carbon stock by soil type for each depth)

\begin{tabular}{|c|c|c|c|c|c|c|}
\hline $\begin{array}{c}\text { Kedalaman } \\
\text { (Depth), } \\
\text { cm }\end{array}$ & $\begin{array}{l}\text { Sumber keragaman } \\
\text { (Source of variation) }\end{array}$ & $\begin{array}{l}\mathrm{Db} \\
(d f)\end{array}$ & $\begin{array}{l}\text { Jumlah } \\
\text { kuadrat } \\
\text { (Sum of } \\
\text { square) }\end{array}$ & $\begin{array}{c}\text { Rata-rata } \\
\text { kuadrat } \\
\text { (Mean of } \\
\text { square) }\end{array}$ & $\begin{array}{l}\text { F-rasio } \\
(\text { F-ratio })\end{array}$ & $\begin{array}{l}\text { Prob }> \\
\quad F\end{array}$ \\
\hline \multirow{3}{*}{$0-5$} & Tipe tanah (Soil type) & 1 & 892,34 & 892,34 & 20,76 & $<, 0001$ \\
\hline & Galat (Error) & 157 & 6749,31 & 42,99 & & \\
\hline & Total terkoreksi (Corrected total) & 158 & 7641,65 & & & \\
\hline \multirow{3}{*}{$0-10$} & Tipe tanah (Soil type) & 1 & 4143,01 & 4143,01 & 26,91 & $<, 0001$ \\
\hline & Galat (Error) & 157 & 24168,76 & 153,94 & & \\
\hline & Total terkoreksi (Corrected total) & 158 & 28311,77 & & & \\
\hline \multirow{3}{*}{$0-20$} & Tipe tanah (Soil type) & 1 & 8870,16 & 8870,16 & 21,37 & $<, 0001$ \\
\hline & Galat (Error) & 157 & 65180,16 & 415,16 & & \\
\hline & Total terkoreksi (Corrected total) & 158 & 74050,32 & & & \\
\hline \multirow{3}{*}{$0-30$} & Tipe tanah (Soil type) & 1 & 10154,46 & 10154,5 & 17,66 & $<, 0001$ \\
\hline & Galat (Error) & 157 & 90279,75 & 575,0 & & \\
\hline & Total terkoreksi (Corrected total) & 158 & 100434,21 & & & \\
\hline \multirow{3}{*}{$0-50$} & Tipe tanah (Soil type) & 1 & 3838,71 & 3838,71 & 10,36 & 0,0050 \\
\hline & Galat (Error) & 17 & 6299,82 & 370,58 & & \\
\hline & Total terkoreksi (Corrected total) & 18 & 10138,54 & & & \\
\hline \multirow{3}{*}{$0-70$} & Tipe tanah (Soil type) & 1 & 2744,56 & 2744,56 & 4,38 & 0,0516 \\
\hline & Galat (Error) & 17 & 10645,70 & 626,22 & & \\
\hline & Total terkoreksi (Corrected total) & 18 & 13390,26 & & & \\
\hline \multirow{3}{*}{$0-100$} & Tipe tanah (Soil type) & 1 & 919,42 & 919,42 & 0,873 & 0,3632 \\
\hline & Galat (Error) & 17 & 17904,64 & 1053,21 & & \\
\hline & Total terkoreksi (Corrected total) & 18 & 18824,06 & & & \\
\hline
\end{tabular}

